\title{
2 Secondary organic aerosol formation from $\alpha$-pinene, alkanes and oil 3 sands related precursors in a new oxidation flow reactor
}

\author{
4 Kun Li, John Liggio, Patrick Lee, Chong Han, Qifan Liu, and Shao-Meng Li \\ 5 Air Quality Research Division, Environment and Climate Change Canada, Toronto, Ontario M3H 5T4, Canada. \\ 6 Correspondence: John Liggio (john.liggio@ canada.ca)

\section{S1. OFR comparisons}

The design of the ECCC-OFR (Environment and Climate Change Canada oxidation flow reactor) was partially based upon recent OFRs designs (Lambe et al., 2011;Huang et al., 2017;Simonen et al., 2017) with several small specific differences. The specific differences and similarities between the various reported OFRs is described below. Comparison with the PAM (Potential Aerosol Mass) reactor (Lambe et al., 2011):

The ECCC-OFR utilizes a conical diffusion inlet, while PAM employs a straight inlet. The straight inlet is likely to lead to some jetting and recirculation, while cone inlet should have improved fluid dynamics (Huang et al., 2017; Mitroo et al., 2018). The lamps of the ECCC-OFR are located on the outside of the reactor, while the lamps for the PAM are located inside the reactor which can increase surface-to-volume ratio and hence wall losses. Finally, both OFRs sample from the center with appropriate side flows as exhaust, however the ECCC-OFR uses a sampling tube which is $12.7 \mathrm{~cm}$ offset from the end of the OFR.

Comparison with CPOT (Caltech Photooxidation Flow Tube) (Huang et al., 2017):

Both of these OFRs use a conical diffusion inlet, with the lamps of both located out of the reactor. The ECCC-OFR samples from a center port, while CPOT samples all gases at the exit cone. The CPOT has a larger surface-tovolume ratio and a longer residence time $(\sim 1500 \mathrm{~s})$ compared to the ECCC-OFR, which may lead to larger wall losses of particles and organic vapors.

Comparison with TSAR (TUT Secondary Aerosol Reactor) (Simonen et al., 2017):

Both of these OFRs make use of a conical inlet, with lamps located on the outside of the reactor. These OFRs both sample from the OFR center-line, with sampling tubes offset from the end of the reactors. The TSAR is designed for rapidly changing sources, with a volume that is smaller $(3.3 \mathrm{~L})$ and a residence time which is shorter $(37 \mathrm{~s})$ (Simonen et al., 2017). As a result, the OH concentration within the TSAR will be higher at the same OH exposure. The LVOCs inside the reactor can be consumed by high concentration of $\mathrm{OH}$, or exit the OFR because due to insufficient time to condense on aerosols (Simonen et al., 2017). 


\section{S2. OS sample details}

34 OS ore samples were collected directly from the CNRL-Horizon OPP (Ore Preparation Plant) surge bin \#1 on 2435 Sep-2016, and stored in a freezer $\left(-10^{\circ} \mathrm{C}\right)$. Once the oil sands is hauled out of the mine, the ore is first processed in an Ore Preparation Plant (OPP), where clumps of oil sands are broken down (OPP-dry) and mixed with water to produce a pumpable slurry (OPP-wet). Mined oil sands can contain large chucks of bitumen, ice and fine solids. The crusher and sizer of the OPP-dry process breaks these clumps down into a loose, unconsolidated material (OSM, 2019). The OS ore sample here is from the surge bin after the OPP-dry process, which can be considered as "unprocessed" OS ore.

Bitumen was collected from the bitumen froth from the CNRL-Horizon plant on 25-Sep-2016, and stored in a freezer $\left(-10{ }^{\circ} \mathrm{C}\right)$. Bitumen froth is extracted from the oil sands slurry (after OPP-wet) through a simple water-based gravity separation process, which occurs in a large cone-bottomed vessel. The bitumen attaches to free air bubbles and rises to the top of the vessel, forming an intermediate froth product (the bitumen samples here) (OSM, 2019).The heavy sand sinks to the bottom and is pumped out to the tailings plant (OSM, 2019). Bitumen froth contains about $50-60 \%$ bitumen, $30-40 \%$ water and $10-15 \%$ fine solids.

Naphtha solvent was collected from the CNRL-Horizon facility on 25-Sep-2016, and stored in a refrigerator $\left(\sim 4{ }^{\circ} \mathrm{C}\right)$. toluene, ethylbenzene, xylenes) (Siddique et al., 2006).

Dilbit is diluted bitumen, and was collected from the CNRL-Horizon facility on 25-Sep-2016, and stored in a refrigerator $\left(\sim 4{ }^{\circ} \mathrm{C}\right)$. Though bitumen froth contains only $\sim 60 \%$ bitumen, it acts almost like a single-phase fluid. The water and bitumen are closely intermixed, with fine solids trapped within the viscous mixture (OSM, 2019). Therefore, bitumen froth is further processed by froth treatment, which is accomplished through the addition of a solvent or diluent (e.g., naphtha). This solvent/diluent dilutes the bitumen, producing a less viscous, lighter product, with a density lower than water. The viscosity of the diluted bitumen also drops significantly, which releases the trapped fines. The diluted bitumen floats to the top of the gravity separation vessel, leaving the fines to settle to the bottom of the water phase (OSM, 2019). Bitumen itself is extremely heavy and viscous, and cannot be transported in pipelines. The diluted bitumen also makes the transport in pipelines possible for bitumen products.

Tailings pond water was collected from Suncor pond $2 / 3$ on 23-Aug-2017, and stored in a refrigerator $\left(\sim 4{ }^{\circ} \mathrm{C}\right)$. Tailings are a mixture of water, fine silts, residual bitumen, salts and soluble organic compounds. They also include solvents (e.g., naphtha) that are added to the oil sands during the separation process. Suncor tailings pond $2 / 3$ is considered as one of the most active tailings ponds in the Alberta OS region (Small et al., 2015). 
The total ion chromatogram of the OS-related precursors as a function of retention time for GC-MS are shown in Fig. S2. The retention time for $n$-alkane standards are also shown. Here we assume that the unresolved complex mixture between $C_{n}$ to $C_{n+1}$ alkanes have lower volatility than $C_{n}$ and higher volatility than $C_{n+1}$, and bin the data (after response factor correction for compounds with different volatilities) by carbon number in Fig. 5a. According to the relationship between carbon number and volatility (Donahue et al., 2006), the data are also binned by effective saturation concentration $\left(\mathrm{C}^{*}\right)$ in Fig. 5b. For OS ore, the volatility covers a wide range of carbon number from 6 to 15. Based on the mass fraction of each carbon number, we calculated the average carbon number of OS ore, which is $\sim 10$ (9.79). As a commonly used solvent in OS processing, the naphtha has a narrow distribution mainly at $\mathrm{C}_{6}-\mathrm{C}_{8}$, with a peak at $\mathrm{C}_{7}$. The VD of OS ore and bitumen are very similar at a retention time of $>4$ min (Fig. S2), which corresponds to approximately $\mathrm{C}_{8}$, and indicates that the processed bitumen is essentially oil sands mixed with some solvents during the processing. Bitumen, dilbit and tailings pond water contain varying amounts of the similar solvents, consistent with the dominant volatility at $\mathrm{C}_{7}$ for these samples. Based on the VDs in Fig. 5, the fraction of solvent within the emissions follows the order of naphtha $(100 \%$ solvent $)>$ dilbit $>$ tailings pond $>$ bitumen $>$ OS ore ( $0 \%$ solvent). This corresponds to a non-solvent fraction in the sample vapors in the order of OS ore > bitumen > tailings pond > dilbit > naphtha ( $0 \%$ heavy oil). From the VDs in Fig. 5, it is also found that the vapors from OS ore and bitumen contain $\sim 15 \%$ and $\sim 10 \%$ IVOCs (carbon number $\geq 12, \mathrm{C}^{*} \leq 10^{6} \mu \mathrm{g} \mathrm{m}^{-3}$ ), respectively, while other precursors are almost 100\% VOCs.

We note that VD of OS ore measured here is somewhat different from that previously measured (Liggio et al., 2016), which were mainly in the $\mathrm{C}_{12}$ to $\mathrm{C}_{16}$ range. However, the VD for OS ore in this study is mainly from $\mathrm{C}_{8}$ to $\mathrm{C}_{13}$ with an average value of $\mathrm{C}_{10}$, which are more volatile than the previous study. This difference is likely due to the nature of the samples themselves, as the previous OS ore sample was collected off-site, in an area not associated with active mining, and exposed to the atmosphere for a long period. It is highly likely that the majority of the more volatile components had long since evaporated. Conversely, the current study utilized samples taken directly from the active mining operations ( $>50 \mathrm{~m}$ below ground) and immediately archived at $-10{ }^{\circ} \mathrm{C}$. In addition, the VD derived here are consistent with those from more recent aircraft measurements around active mining operations.

\section{S4. SOA yield calculations}

93 The SOA yields $(\mathrm{Y})$ are calculated using the mass concentration of organic aerosols $\left(\Delta \mathrm{M}_{\mathrm{O}}\right)$ and reacted parent 94 hydrocarbons $(\triangle \mathrm{HC})$ :

$$
\mathrm{Y}=\Delta \mathrm{M}_{\mathrm{O}} / \Delta \mathrm{HC}
$$

96 Here, $\Delta \mathrm{M}_{\mathrm{O}}$ is calculated by multiplying the integrated volume concentration by the effective particle density (see 97 Methods). The calculation for $\triangle \mathrm{HC}$ is based on the measured THC. From the measured total carbon (converted $\mathrm{CO}_{2}$ ) 98 mixing ratio, one can derive the carbon mass concentration $[\mathrm{C}]$. For single precursors (which contains only $\mathrm{C}$ and $\mathrm{H}$ ), the precursor mass concentration $[\mathrm{HC}]$ is calculated by: 


$$
[H C]=[C] \times\left(1+\frac{H / C}{12}\right)
$$

The reacted hydrocarbon mass concentration is then calculated by:

$$
\Delta H C=[H C] \times\left(1-e^{(-k \cdot[O H] \cdot t)}\right)
$$

where $\mathrm{k}$ is the second-order rate constant of the precursor with $\mathrm{OH} ;[\mathrm{OH}] \cdot \mathrm{t}$ is the $\mathrm{OH}$ exposure, which is measured 104 off-line via the decay of CO (see Methods).

For OS-related precursors, the molecular composition (and hence H/C and k) is unknown, hence there are several assumptions when applying the above steps. The $\mathrm{H} / \mathrm{C}$ of the $\mathrm{OS}$ precursors $\left(\mathrm{H} / \mathrm{C}_{\mathrm{OS}}\right)$ is estimated via the intercept of the linear fit of the Van Krevelen diagram of OS SOA (Fig. S5, Table S1). The intercept represents the H/C ratio when $\mathrm{O} / \mathrm{C}$ ratio is zero, which is expected to be similar to the precursor $\mathrm{H} / \mathrm{C}$. However, based on the intercept and the precursor $\mathrm{H} / \mathrm{C}$ of the alkanes (Table S1), we find that the intercept generally underestimates the precursor $\mathrm{H} / \mathrm{C}$, with a correlation of $\mathrm{H} / \mathrm{C}=0.606+0.768 \times$ Intercept $\left(\mathrm{R}^{2}=0.97\right)$. The $H / \mathrm{C}_{\mathrm{OS}}$ are then calculated based on this equation, and are shown in Table S1. The uncertainty of this approach is estimated to be within \pm 0.1 , which corresponds to minor uncertainty (less than $1 \%$ ) in the calculated mass of OS precursors.

Based on the VDs of OS precursors as a function of carbon number (Fig. 5a), the reacted OS precursor mass concentration is estimated by two approaches. First, using the rate constants of the $n$-alkanes $\left(\mathrm{C}_{6}-\mathrm{C}_{15}\right)$ to calculate the reacted precursor in each bin, and adding them together to obtain the total reacted mass concentration. Second, using the rate constant of the $n$-alkane similar to the average carbon number (e.g., $\mathrm{C}_{10}$ for OS ore, see Sect. S3) as the rate constant of the OS precursor and calculating the reacted mass concentration. Figure S3 shows the calculated yields using these two approaches for OS ore. These two approaches give very similar yields, with both of them higher than the SOA potential (assuming all precursor reacted) at photochemical age of < 3 days. After 3 days, all of the curves are identical since the precursors are $100 \%$ reacted. In addition, we also calculate the yields assuming the OS ore has a rate constant of cyclodecane, with calculated yields slightly lower than assuming it to be $n$-decane. For other OS-related precursors, the results are similar to OS ore. As these approaches give very similar results and the average carbon method is simpler to conduct, the SOA yields of OS precursors shown in this study are all calculated based on the average carbon method using the rate constant of corresponding $n$-alkanes.

The carbon and oxygen yields $\left(\mathrm{Y}_{\mathrm{C}}\right.$ and $\left.\mathrm{Y}_{\mathrm{O}}\right)$ are also shown in this study, which are calculated by the method described previously (Kroll et al., 2009;Lambe et al., 2012):

$$
\begin{gathered}
Y_{C}=Y \times \frac{12}{12+16 \times 0 / C+H / C} \\
Y_{O}=\frac{Y_{C} \times O / C \times 16}{12}
\end{gathered}
$$

\section{S5. LVOCs fate correction}


The fate of the LVOCs in the OFR include condensation on the reactor wall, exiting the reactor, and reacting with $\mathrm{OH}$ to form higher volatility compounds that are not condensable. These three losses may influence the LVOC fate, which in the atmosphere is expected to be condensation to pre-existing aerosol. Here, the method developed by Palm et al. (2016) was used to correct for these losses. Briefly, the lifetimes of LVOCs associated with these processes were used to estimate the fractional loss of each process. These lifetimes are $\tau_{\text {aerosol }}$ (condense on aerosol), $\tau_{\text {wall }}$ (condense on reactor wall), and $\tau_{\mathrm{OH}}$ (react with $\mathrm{OH}$ to form non-condensable compounds) and their parametrization is described below:

1. $\tau_{\text {aerosol }}$ is estimated by (Pirjola et al., 1999):

$$
\tau_{\text {aerosol }}=1 /(4 \pi \cdot C S \cdot D)
$$

where $\mathrm{D}$ is the diffusion coefficient, which is estimated to be $7 \times 10^{-6} \mathrm{~m}^{2} \mathrm{~s}^{-1}$ for oxidized organic vapor with a molecular weight of $200 \mathrm{~g} \mathrm{~mol}^{-1}$ (Tang et al., 2015); CS is the "condensational sink", which represents the sink associated with aerosols and is related to particle size distribution:

$$
C S=\sum_{i} r_{i} \beta_{i} N_{i}
$$

where $r_{i}$ and $N_{i}$ are the particle radius and number concentration of each size bin of SMPS. The $\beta$ term is the correction factor for gaseous diffusion to the particle surface:

$$
\beta=\frac{K n+1}{0.377 K n+1+\frac{4}{3} \alpha^{-1} K n^{2}+\frac{4}{3} \alpha^{-1} K n}
$$

where $\alpha$ is the mass accommodation coefficient (also known as the sticking coefficient) of condensing vapor, which is assumed to be $1 ; K n$ is the Knudsen number:

$$
K n=3 \sqrt{\frac{\pi M}{8 R T}} \frac{D}{r}
$$

where $M$ is the molecular weight of the condensing vapor, which is assumed to be $200 \mathrm{~g} \mathrm{~mol}^{-1} ; R$ is the gas constant; $T$ is the temperature.

2. $\tau_{\text {wall }}$ is estimated by (McMurry and Grosjean, 1985):

$$
\tau_{\text {wall }}=\frac{\pi}{2 \frac{A}{V} \sqrt{k_{e} D}}
$$

where $A / V$ is the surface-area-to-volume ratio, which is $22.3 \mathrm{~m}^{-1}$ for our OFR; $k_{e}$ is the eddy diffusion coefficient (Krechmer et al., 2016):

$$
k_{e}=0.004+0.0056 \cdot V^{0.74}
$$

3. It is assumed that after reacting five times with $\mathrm{OH}$, the LVOCs are fragmented to small molecules that are too volatile to condense (Palm et al., 2016). Hence, $\tau_{\mathrm{OH}}$ is estimated by: 


$$
\tau_{O H}=\frac{5}{k_{O H} \cdot[\mathrm{OH}]}
$$

where $k_{O H}$ is the rate constant for reaction with $\mathrm{OH}$, which is assumed to be $1 \times 10^{-11} \mathrm{~cm}^{3} \mathrm{molec}^{-1} \mathrm{~s}^{-1}$ (Ziemann and Atkinson, 2012).

Using the three lifetimes above, the total lifetime of these three pathways $\left(\tau_{\text {total }}\right)$ can be estimated by:

$$
\frac{1}{\tau_{\text {total }}}=\frac{1}{\tau_{\text {aerosol }}}+\frac{1}{\tau_{\text {wall }}}+\frac{1}{\tau_{O H}}
$$

Combined with the residence time $\left(\tau_{\mathrm{OFR}}\right)$, the fraction that exit the OFR $\left(\mathrm{F}_{\text {exit }}\right)$, condense on aerosol $\left(\mathrm{F}_{\mathrm{aerosol}}\right)$, condense on reactor wall $\left(\mathrm{F}_{\mathrm{wall}}\right)$, and react with $\mathrm{OH}\left(\mathrm{F}_{\mathrm{OH}}\right)$ can be estimated using the following equations:

$$
F_{\text {exit }}=e^{-\frac{\tau_{\text {OFR }}}{\tau_{\text {total }}}}
$$

$$
F_{\text {aerosol }}=\left(1-F_{\text {exit }}\right) \cdot \frac{\tau_{\text {total }}}{\tau_{\text {aerosol }}}
$$$$
F_{\text {wall }}=\left(1-F_{\text {exit }}\right) \cdot \frac{\tau_{\text {total }}}{\tau_{\text {wall }}}
$$

$$
F_{O H}=\left(1-F_{\text {exit }}\right) \cdot \frac{\tau_{\text {total }}}{\tau_{O H}}
$$

According to the sensitivity analysis performed previously (Palm et al., 2016), variations in most of parameters above have little influence on the results with the exception of CS and $\alpha$. The CS that used in this method is the average value at the beginning and the end of the reactor. Using a CS at the beginning of the reactor will largely enhance the correction factor. However, as organic aerosols are formed through the entire reactor, using the average $\mathrm{CS}$ is more reasonable. Varying $\alpha$ from 1 to 0.1 also largely enhances the correction factor. However, according to a recent study (Krechmer et al., 2017), the accommodation coefficient was quantified to be $\sim 1$. Hence the influence from $\alpha$ is likely to be small. Overall, we assume that the uncertainty associated with this correction approach is within $\pm 30 \%$.

When applying the above correction to SOA yields, one needs to know the LVOCs fraction in SOA. The LVOCs and ELVOCs (extremely low volatility VOCs) in the atmosphere are $\sim 100 \%$ in the particle phase, while the S/IVOCs may be partially in the gas phase, depending on the organic aerosol concentration. As a result, a OFR fate correction for S/IVOCs is not feasible. Previous field measurements and laboratory studies demonstrated that SOA from various sources were mainly 40\%-80\% L/ELVOCs and 20\%-60\% S/IVOCs (Hong et al., 2017;Saha et al., 2017;D’Ambro et al., 2018;Sato et al., 2018;Saha et al., 2018). In our experiments, the low-NO $\mathrm{N}_{\mathrm{x}}$ yields are significantly higher than the high- $\mathrm{NO}_{\mathrm{x}}$ yields (paper in preparation), indicating a lower volatility for SOA formed under low- $\mathrm{NO}_{\mathrm{x}}$ conditions. Hence, the upper limit of the fraction (80\%) is used for the LVOCs correction of low$\mathrm{NO}_{\mathrm{x}}$ yields. The $20 \% \mathrm{~S} / \mathrm{IVOCs}$ in SOA remain unchanged. Previous studies have assumed SOA to be $100 \% \mathrm{LVOCs}$ (Ortega et al., 2016;Palm et al., 2016), and the 80\% LVOCs used here leads to slightly lower correction factors. 


\section{S6. Conversion efficiency determination of the THC system}

\section{Figures and Tables}

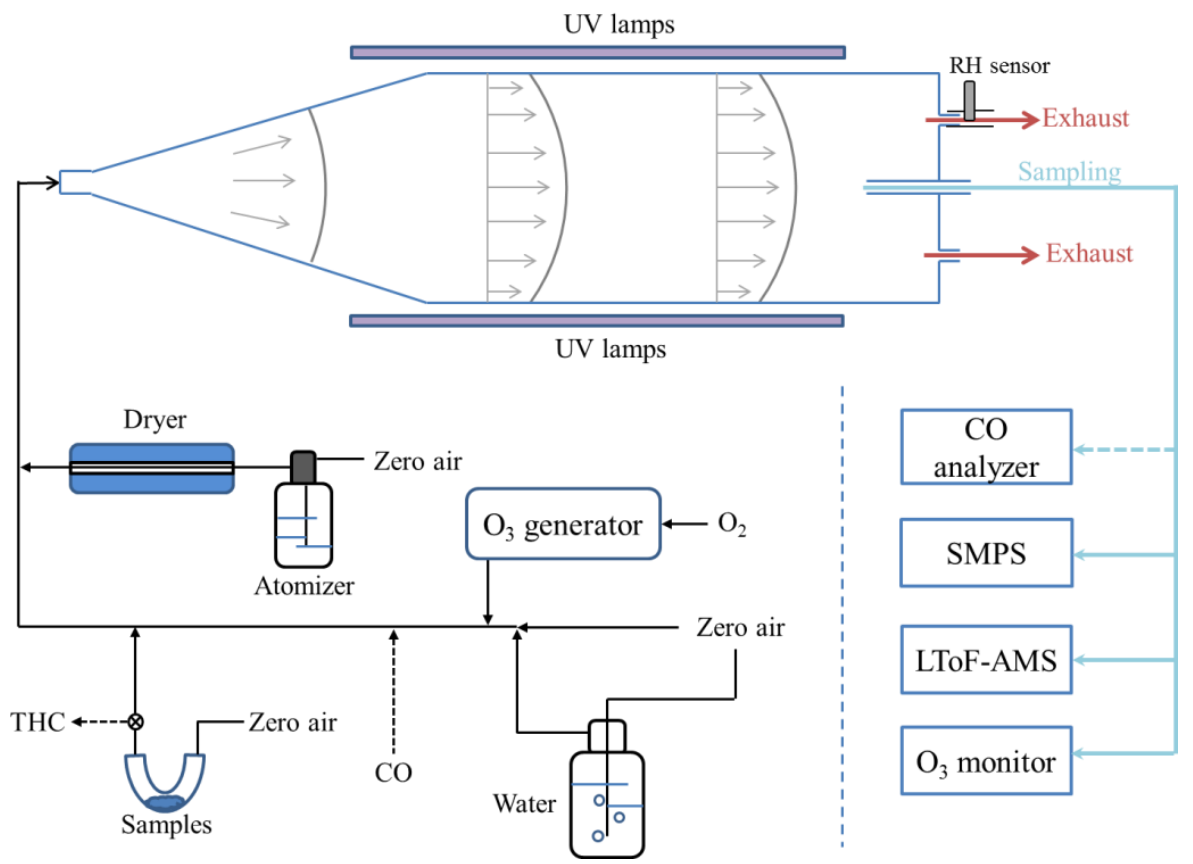
the molecular weight; $P$ is the atmospheric pressure; $F_{g}$ is the zero air flow rate.

$$
H C(p p b)=\frac{R T \rho F_{l} \times 10^{9}}{M P F_{g}}
$$

203 Figure S1. Schematic diagram of the ECCC-OFR and associated experimental setup. 


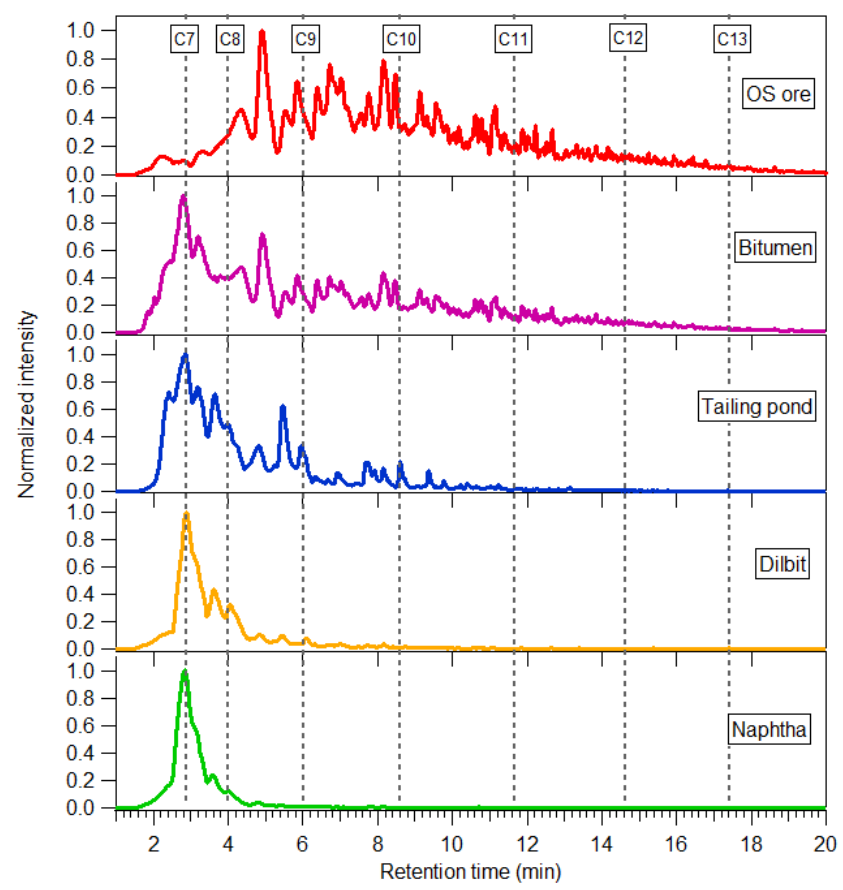

Figure S2. GC-MS chromatogram of the OS-related precursors. Dashed lines indicate the retention time of the $n$ -

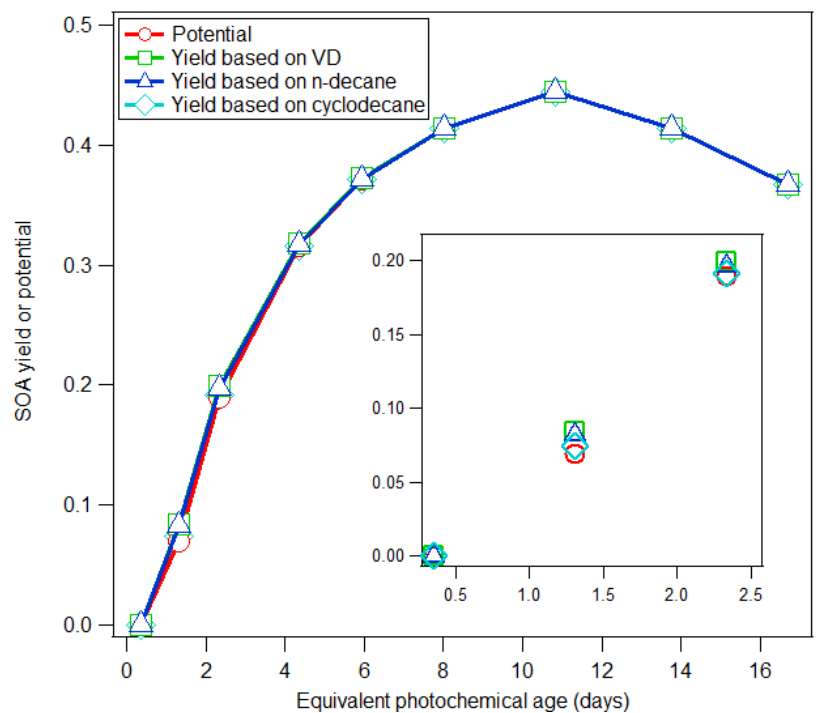

Figure S3. OS ore SOA potential and yield based on the reaction rate constant from the VD, $n$-decane and cyclodecane. The inset shows the first three photochemical ages. 


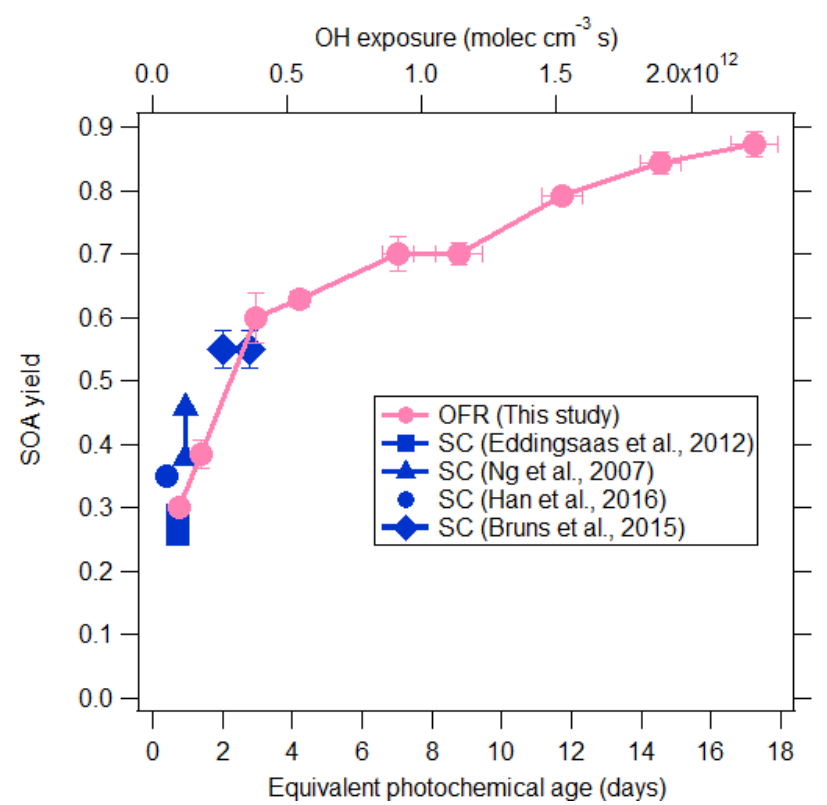

214 Figure S4. Comparison of LVOCs fate corrected SOA yields for $\alpha$-pinene with previous smog chamber studies ( $\mathrm{Ng}$ 215 et al., 2007;Eddingsaas et al., 2012;Bruns et al., 2015;Han et al., 2016).

216

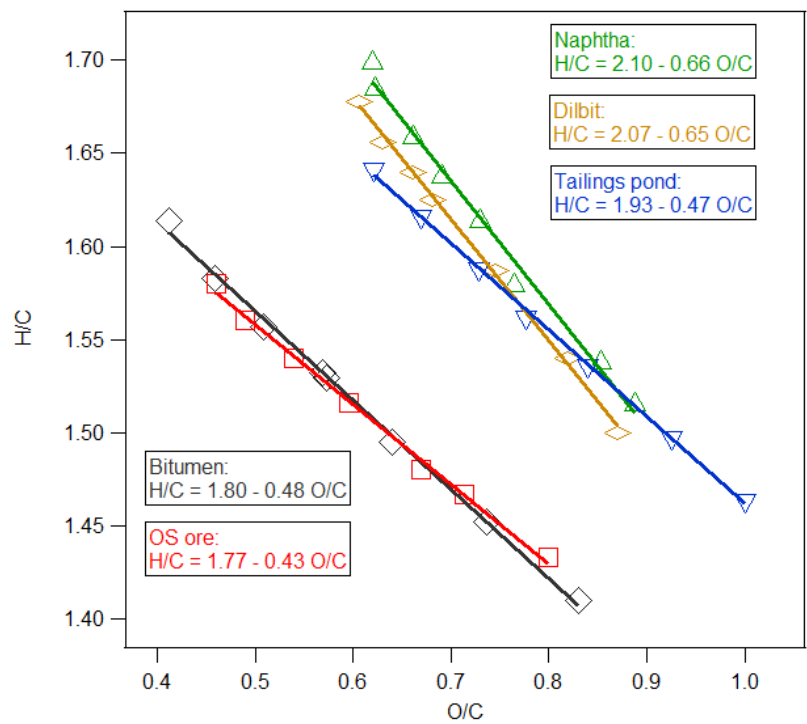

218 Figure S5. Linear regression of the $\mathrm{H} / \mathrm{C}$ versus $\mathrm{O} / \mathrm{C}$ ratios of SOA formed from OS-related precursors. 


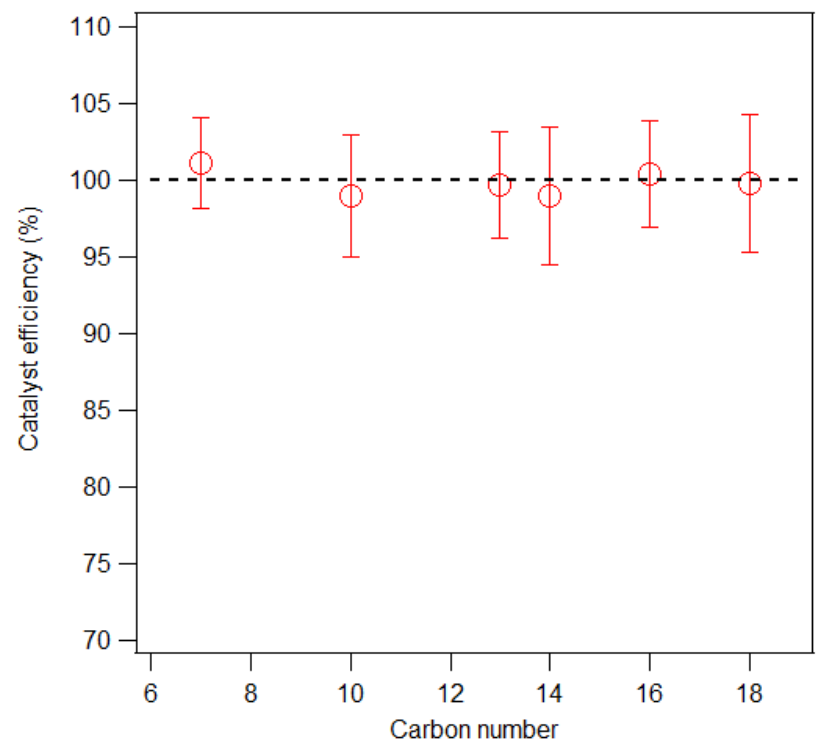

221 Figure S6. Catalyst efficiencies of the THC system for toluene and $\mathrm{C}_{10}, \mathrm{C}_{13}, \mathrm{C}_{14}, \mathrm{C}_{16}$, and $\mathrm{C}_{18} n$-alkanes.

Table S1. Intercept and slope of the linear regression of the H/C versus O/C ratios in Fig. $6 b$, and the $\mathrm{H} / \mathrm{C}$ ratio of the precursors.

\begin{tabular}{|l|l|l|l|l|}
\hline Precursor & Intercept & Slope & $\mathrm{R}^{2}$ & Precursor H/C \\
\hline$n$-Heptane (C7) & 2.17 & -0.63 & 0.983 & 2.29 \\
\hline$n$-Decane (C10) & 2.12 & -0.72 & 0.996 & 2.2 \\
\hline$n$-Dodecane (C12) & 2.04 & -0.70 & 0.996 & 2.17 \\
\hline Cyclodecane & 1.76 & -0.43 & 0.995 & 2 \\
\hline Decalin & 1.59 & -0.32 & 0.999 & 1.8 \\
\hline Naphtha & 2.10 & -0.66 & 0.989 & $2.22^{\mathrm{a}}$ \\
\hline Dilbit & 2.07 & -0.65 & 0.998 & $2.2^{\mathrm{a}}$ \\
\hline Tailings pond & 1.93 & -0.47 & 0.999 & $2.09^{\mathrm{a}}$ \\
\hline Bitumen & 1.80 & -0.48 & 0.997 & $1.99^{\mathrm{a}}$ \\
\hline OS ore & 1.77 & -0.43 & 0.996 & $1.96^{\mathrm{a}}$ \\
\hline
\end{tabular}

a. Calculated based on the linear fitting result of precursor H/C and intercept for alkanes (see Sect. S4).

\section{References}

Bruns, E. A., El Haddad, I., Keller, A., Klein, F., Kumar, N. K., Pieber, S. M., Corbin, J. C., Slowik, J. G., Brune, W. H., Baltensperger, U., and Prévôt, A. S. H.: Inter-comparison of laboratory smog chamber and flow reactor systems on organic aerosol yield and composition, Atmospheric Measurement Techniques, 8, 2315-2332, 10.5194/amt-8-2315-2015, 2015.

D’Ambro, E. L., Schobesberger, S., Zaveri, R. A., Shilling, J. E., Lee, B. H., Lopez-Hilfiker, F. D., Mohr, C., and Thornton, J. A.: Isothermal Evaporation of $\alpha$-Pinene Ozonolysis SOA: Volatility, Phase State, and Oligomeric Composition, ACS Earth and Space Chemistry, 2, 1058-1067, 10.1021/acsearthspacechem.8b00084, 2018. 
Donahue, N. M., Robinson, A. L., Stanier, C. O., and Pandis, S. N.: Coupled partitioning, dilution, and chemical aging of semivolatile organics, Environmental science \& technology, 40, 2635-2643, 10.1021/es052297c, 2006.

Eddingsaas, N. C., Loza, C. L., Yee, L. D., Chan, M., Schilling, K. A., Chhabra, P. S., Seinfeld, J. H., and Wennberg, P. O.: $\alpha-$ pinene photooxidation under controlled chemical conditions \&ndash; Part 2: SOA yield and composition in low- and high$\mathrm{NO}<\mathrm{sub}>\mathrm{x}</$ sub $>$ environments, Atmospheric Chemistry and Physics, 12, 7413-7427, 10.5194/acp-12-7413-2012, 2012.

Han, Y., Stroud, C. A., Liggio, J., and Li, S.-M.: The effect of particle acidity on secondary organic aerosol formation from \&lt;i\&gt; $\alpha \& l t ; / i \& g t ;-$ pinene photooxidation under atmospherically relevant conditions, Atmospheric Chemistry and Physics, 16, 13929-13944, 10.5194/acp-16-13929-2016, 2016.

Hong, J., Äijälä, M., Häme, S. A. K., Hao, L., Duplissy, J., Heikkinen, L. M., Nie, W., Mikkilä, J., Kulmala, M., Prisle, N. L., Virtanen, A., Ehn, M., Paasonen, P., Worsnop, D. R., Riipinen, I., Petäjä, T., and Kerminen, V.-M.: Estimates of the organic aerosol volatility in a boreal forest using two independent methods, Atmospheric Chemistry and Physics, 17, 43874399, 10.5194/acp-17-4387-2017, 2017.

Huang, Y., Coggon, M. M., Zhao, R., Lignell, H., Bauer, M. U., Flagan, R. C., and Seinfeld, J. H.: The Caltech Photooxidation Flow Tube reactor: design, fluid dynamics and characterization, Atmospheric Measurement Techniques, 10, 839-867, 10.5194/amt-10-839-2017, 2017.

Krechmer, J. E., Pagonis, D., Ziemann, P. J., and Jimenez, J. L.: Quantification of Gas-Wall Partitioning in Teflon Environmental Chambers Using Rapid Bursts of Low-Volatility Oxidized Species Generated in Situ, Environmental science \& technology, 50, 5757-5765, 10.1021/acs.est.6b00606, 2016.

Krechmer, J. E., Day, D. A., Ziemann, P. J., and Jimenez, J. L.: Direct Measurements of Gas/Particle Partitioning and Mass Accommodation Coefficients in Environmental Chambers, Environmental science \& technology, 51, 11867-11875, 10.1021/acs.est.7b02144, 2017.

Kroll, J. H., Smith, J. D., Che, D. L., Kessler, S. H., Worsnop, D. R., and Wilson, K. R.: Measurement of fragmentation and functionalization pathways in the heterogeneous oxidation of oxidized organic aerosol, Physical Chemistry Chemical Physics, 11, 8005-8014, 10.1039/b905289e, 2009.

Lambe, A. T., Ahern, A. T., Williams, L. R., Slowik, J. G., Wong, J. P. S., Abbatt, J. P. D., Brune, W. H., Ng, N. L., Wright, J. P., Croasdale, D. R., Worsnop, D. R., Davidovits, P., and Onasch, T. B.: Characterization of aerosol photooxidation flow reactors: heterogeneous oxidation, secondary organic aerosol formation and cloud condensation nuclei activity measurements, Atmospheric Measurement Techniques, 4, 445-461, 10.5194/amt-4-445-2011, 2011.

Lambe, A. T., Onasch, T. B., Croasdale, D. R., Wright, J. P., Martin, A. T., Franklin, J. P., Massoli, P., Kroll, J. H., Canagaratna, M. R., Brune, W. H., Worsnop, D. R., and Davidovits, P.: Transitions from functionalization to fragmentation reactions of laboratory secondary organic aerosol (SOA) generated from the $\mathrm{OH}$ oxidation of alkane precursors, Environmental science \& technology, 46, 5430-5437, 10.1021/es300274t, 2012.

Liggio, J., Li, S. M., Hayden, K., Taha, Y. M., Stroud, C., Darlington, A., Drollette, B. D., Gordon, M., Lee, P., Liu, P., Leithead, A., Moussa, S. G., Wang, D., O'Brien, J., Mittermeier, R. L., Brook, J. R., Lu, G., Staebler, R. M., Han, Y., Tokarek, T. W., Osthoff, H. D., Makar, P. A., Zhang, J., Plata, D. L., and Gentner, D. R.: Oil sands operations as a large source of secondary organic aerosols, Nature, 534, 91-94, 10.1038/nature17646, 2016.

McMurry, P. H., and Grosjean, D.: GAS AND AEROSOL WALL LOSSES IN TEFLON FILM SMOG CHAMBERS, Environmental science \& technology, 19, 1176-1182, 10.1021/es00142a006, 1985.

Mitroo, D., Sun, Y., Combest, D. P., Kumar, P., and Williams, B. J.: Assessing the degree of plug flow in oxidation flow reactors (OFRs): a study on a potential aerosol mass (PAM) reactor, Atmospheric Measurement Techniques, 11, 1741-1756, 10.5194/amt-11-1741-2018, 2018. 
Ng, N. L., Chhabra, P. S., Chan, A. W. H., Surratt, J. D., Kroll, J. H., Kwan, A. J., McCabe, D. C., Wennberg, P. O., Sorooshian, A., Murphy, S. M., Dalleska, N. F., Flagan, R. C., and Seinfeld, J. H.: Effect of NO(x) level on secondary organic aerosol (SOA) formation from the photooxidation of terpenes, Atmospheric Chemistry and Physics, 7, 5159-5174, 2007.

Ortega, A. M., Hayes, P. L., Peng, Z., Palm, B. B., Hu, W., Day, D. A., Li, R., Cubison, M. J., Brune, W. H., Graus, M., Warn eke, C., Gilman, J. B., Kuster, W. C., de Gouw, J., Gutiérrez-Montes, C., and Jimenez, J. L.: Real-time measurements of secondary organic aerosol formation and aging from ambient air in an oxidation flow reactor in the Los Angeles area, Atmospheric Chemistry and Physics, 16, 7411-7433, 10.5194/acp-16-7411-2016, 2016.

OSM: Oil Sands Magazine, Technical Guides, https://www.oilsandsmagazine.com/technical/ (last access: 13 February 2019), 2019.

Palm, B. B., Campuzano-Jost, P., Ortega, A. M., Day, D. A., Kaser, L., Jud, W., Karl, T., Hansel, A., Hunter, J. F., Cross, E. S., Kroll, J. H., Peng, Z., Brune, W. H., and Jimenez, J. L.: In situ secondary organic aerosol formation from ambient pine forest air using an oxidation flow reactor, Atmospheric Chemistry and Physics, 16, 2943-2970, 10.5194/acp-16-2943-2016, 2016.

Pirjola, L., Kulmala, M., Wilck, M., Bischoff, A., Stratmann, F., and Otto, E.: FORMATION OF SULPHURIC ACID AEROSOLS AND CLOUD CONDENSATION NUCLEI: AN EXPRESSION FOR SIGNIFICANT NUCLEATION AND MODEL COMPRARISON, Journal of Aerosol Science, 30, 1079-1094, https://doi.org/10.1016/S0021-8502(98)00776-9, 1999.

Saha, P. K., Khlystov, A., Yahya, K., Zhang, Y., Xu, L., Ng, N. L., and Grieshop, A. P.: Quantifying the volatility of organic aerosol in the southeastern US, Atmospheric Chemistry and Physics, 17, 501-520, 10.5194/acp-17-501-2017, 2017.

Saha, P. K., Khlystov, A., and Grieshop, A. P.: Downwind evolution of the volatility and mixing state of near-road aerosols near a US interstate highway, Atmospheric Chemistry and Physics, 18, 2139-2154, 10.5194/acp-18-2139-2018, 2018.

Sato, K., Fujitani, Y., Inomata, S., Morino, Y., Tanabe, K., Ramasamy, S., Hikida, T., Shimono, A., Takami, A., Fushimi, A., Kondo, Y., Imamura, T., Tanimoto, H., and Sugata, S.: Studying volatility from composition, dilution, and heating measurements of secondary organic aerosols formed during \&lt;i\&gt; \&\&lt;/i\&gt;-pinene ozonolysis, Atmospheric Chemistry and Physics, 18, 5455-5466, 10.5194/acp-18-5455-2018, 2018.

Siddique, T., Fedorak, P. M., and Foght, J. M.: Biodegradation of Short-Chain n-Alkanes in Oil Sands Tailings under Methanogenic Conditions, Environmental science \& technology, 40, 5459-5464, 10.1021/es060993m, 2006.

Simonen, P., Saukko, E., Karjalainen, P., Timonen, H., Bloss, M., Aakko-Saksa, P., Rönkkö, T., Keskinen, J., and Dal Maso, M.: A new oxidation flow reactor for measuring secondary aerosol formation of rapidly changing emission sources, Atmospheric Measurement Techniques, 10, 1519-1537, 10.5194/amt-10-1519-2017, 2017.

Small, C. C., Cho, S., Hashisho, Z., and Ulrich, A. C.: Emissions from oil sands tailings ponds: Review of tailings pond parameters and emission estimates, Journal of Petroleum Science and Engineering, 127, 490-501, https://doi.org/10.1016/j.petrol.2014.11.020, 2015.

Tang, M. J., Shiraiwa, M., Pöschl, U., Cox, R. A., and Kalberer, M.: Compilation and evaluation of gas phase diffusion coefficients of reactive trace gases in the atmosphere: Volume 2. Diffusivities of organic compounds, pressure-normalised mean free paths, and average Knudsen numbers for gas uptake calculations, Atmospheric Chemistry and Physics, 15, 5585-5598, 10.5194/acp-15-5585-2015, 2015.

Ziemann, P. J., and Atkinson, R.: Kinetics, products, and mechanisms of secondary organic aerosol formation, Chemical Society reviews, 41, 6582-6605, 10.1039/c2cs35122f, 2012. 